Cahiers $d u$ MONDE RUSSE

\section{Cahiers du monde russe}

Russie - Empire russe - Union soviétique et États indépendants

$50 / 2-3 \mid 2009$

L'Europe orientale, $1650-1730$. Crises, conflits et renouveau

\title{
ДИНАСТИЧЕСКИЙ КРИЗИС РУБЕЖА XVI-XVII ВВ. В РОССИИ И СТЕПЕННАЯ КНИГА
}

La crise dynastique à l'aube du XVII e siècle en Russie et dans le Livre des degrés The "Book of Degrees" and the Russian dynastic crisis of the turn of the seventeenth century

\section{Алексей В. Сиренов}

\section{OpenEdition Journals}

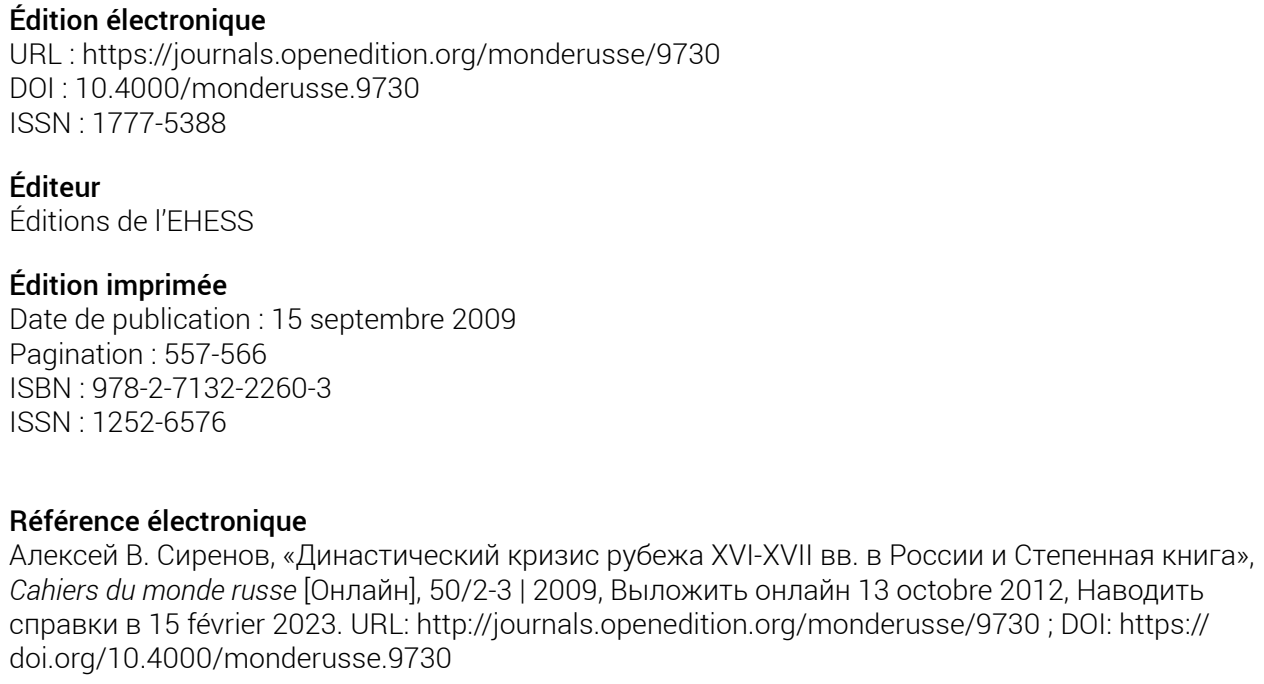




\section{ДИНАСТИЧЕСКИЙ КРИЗИС РУБЕЖА ХVI-XVII ВВ. В РОССИИ И СТЕПЕННАЯ КНИГА}

В XVIв. происходило становление идеологических основ русского централизованного государства. Главным достижением московских политиков стало принятие царского титула Иваном Грозным в 1547 г. и его подтверждение грамотой константинопольского патриарха в 1561 г. Последнее мероприятие было тщательно подготовлено ${ }^{*}$ С середины 50-х гг. вселенским патриархам и в различные монастыри греческого Востока из Москвы рассылались списки царского синодика, в которых перечислялись предки первого русского царя. В этих записях особенно подчеркивалась святость крестителя Руси Владимира Святославича и родство с византийскими императорами Владимира Мономаха. Грамота константинопольского патриарха 1561 г., подтвердившая царский титул Ивана Грозного, показывает, что апелляция к святости и царскому достоинству предков первого русского царя была удачным дипломатическим приемом и привела к нужным результатам. На волне этих событий в Москве был составлен историографический труд принципиально иного характера, чем все предшествующие. В 50-х - начале 60-х гг. XVI в. царский духовник Андрей (в иночестве Афанасий) составил Книгу Степенную царского родословия ${ }^{1}$

\footnotetext{
* Aleksej Sirenov a récemment publié Stepennaja kniga. Istorija teksta [Le Livre des degrés. Histoire du texte], M.: Jazyki slavjanskih kul'tur, 2007.

1. В последнее время Степенная книга стала объектом ислледований Г. Ленхоффа (Gail Lenhoff, "The "Stepennaja kniga" and the Idea of the Book in Medieval Russia», Die Welt der Slaven, Sammelbände/Sborniki, Bd. 21: Germano-Slavistische Beiträge. Festschrift für Peter Rehder zum 65.Geburtstag, Munich, 2004, p. 449-458), Н.Н. Покровского (Н.Н. Покровский, « Исторические постулаты Степенной книги царского родословия », Исторические источники и литературные памятники XVI-XXвв. Развитие традиций, Новосибирск: Изд. СО РАН, 2004, с. 3-36 и др.), А.С. Усачева (А.С. Усачева, « Источники Степенной книги по истории домонгольской Руси », Средневековая Русь, т. 6, М., 2006, с. 210-222 и др.) и автора этих строк (А.В. Сиренов, « Житие князя Владимира и составление Степенной книги », $A E$ 2001, М., 2002, с. 83-94 и др.). Подготовлено и новое критическое издание памятника (Н.Н. Покровский, Г.Д. Ленхофф, отв. ред., Степенная книга царского родословия по древнейшим спискам: Тексты и комментарий, в трех томах, М., 2007, т. 1-2).
} 
Это произведение соединяет подробность и обстоятельность летописного текста с занимательностью и стилистическими красотами житийной литературы. Необычна для древнерусского исторического произведения и композиция текста. Она состоит из 17-ти частей, которые названы в соответствии с традицией Кормчих книг «гранями». Однако есть у этих частей еще одно название - «степени», т.е. «ступени». Каждая грань символизирует очередную ступень, а вся Степенная книга имеет символическое значение лестницы. Как сказано в предисловии к Степенной, перед нами лестница с золотыми ступенями, «по ней же невозбранен к Богу восход». Эти черты роднят Степенную книгу с византийским жанром Лествиц. Уникальность Степенной заключается в том, что сходство ее с Лествицами чисто внешнее и заканчивается разделением текста на степени. Византийские Лествицы повествуют о нравственном восхождении, самоусовершенствовании человека, а Степенная книга рассказывает историю русского народа. Каждая ступень Степенной книги посвящена очередному правителю Руси, князю из рода Рюриковичей, от Владимира Святого до его потомка в семнадцатом колене Ивана Грозного. Таким образом, в основе Степенной лежит другой принцип - генеалогический. Не случайно полное название памятника «Книга Степенная царского родословия». Термин «степень» приобретает здесь значение поколения и переносит нас в область генеалогии. И все-же не случайно Степенная начинает счет поколений не с родоначалника династии Рюрика или его сына Игоря, а с первого христианина на престоле - Владимира. Именно Владимир положил начало новой, христианской истории Руси, при нем началось восхождение русского народа к Богу. Надо сказать, что характеризуя очередного «самодержца», Степенная книга неизменно указывает его порядковый номер по поколениям от Владимира и от Рюрика. Этот двойной счет свидетельствует о том, что генеалогический принцип не был доминирующим при создании Степенной книги. Идеологам Ивана Грозного было особенно важно, чтобы царское родословие начиналось с равноапостольного святого Владимира, а не с язычников Рюрика и Игоря. Эту мысль развил и сам Иван Грозный в Послании Андрею Курбскому: «Сего убо православия истиннаго Росийскаго царствия самодержавство Божиим изволением почен от великаго князя Владимира, просветившаго Рускую землю святым крещением...»². Как видим, с фактом крещения Руси при князе Владимире Иван Грозный связывал и начало самодержавия на Руси. Князь Владимир, таким образом, выступает как основоположник и религиозного, и государственного устройства Руси. Видимо, поэтому в

2. « Первое послание Ивана Грозного Курбскому », Переписка Ивана Грозного с Андреем Курбским, текст подгот. Я.С. Лурье и Ю.Д. Рыков, М.: Наука, 1981, с. 12 [перев. на фрац. яз. Даря Оливье, Ivan le Terrible: Correspondance avec le prince Kourbski, P.: Seghers, 1959]. 
Степенной книге именно он выбран родоначальником царского рода, а его правление символизирует первую ступень лестницы русской истории. Следующая, вторая степень-ступень посвящена сыну Владимира Святославича Ярославу Мудрому, третья степень - сыну Ярослава Всеволоду, червертая - его сыну Владимиру Манамаху. Далее следуют потомки Владимира Мономаха: Юрий Долгорукий (V степень), Всеволод Большое Гнездо (VI степень), Ярослав Всеволодович (VII степень), Александр Невский (VIII степень), Даниил Московский (IX степень), Иван Калита (X степень), Иван Красный (XI степень), Дмитрий Донской (XII степень), Василий I (XIII степень), Василий Темный (XIV степень), Иван III (XV степень), Василий III (XVI степень) и, наконец, Иван Грозный (XVII степень). Эти персонажи стали главными героями русской историографии начиная со Степенной книги и вплоть до трудов В.Н. Татищева и H.M. Карамзина. Выбор их в Степенной книге не случаен - перед нами линия прямых предков Ивана Грозного. Таким образом, задача составителя Степенной состояла в том, чтобы из летописного и житийного материала выбрать известия о прямых предках царя и представить этих князей главными героями отечественной истории. В повествовании Степенной книги всегда есть главный герой, вокруг которого разворачивается действие. «Самодержателем» безусловно объявляется предок Ивана Грозного, а все остальные упоминаемые князья фигурируют как его современники и «сродники».

Степенная книга излагает исторический материал не хронологически, как летописи, а тематически. В этом принципиальное новшество Степенной. Перед нами уже не средневековая хроника, a, скорее, трактат, характерный для Нового времени. Идеологическая заостренность и стилистическая обработка текста нередко приводили к тому, что в изложении фактов появлялась непоследовательность, переходящая порой в искажение и фальсификацию.

Степенная книга сразу же обрела популярность. Ее текст был привлечен при создании Лицевого летописного свода, ее списки в конце XVI в. оказались в библиотеке первого патриарха Иова, а также в ряде крупных монастырей: московском Чудове, Соловецком, владимирском Рождественском.

И все же идеологическая концепция Степенной книги устарела уже к концу XVI в. Последний представитель династии московских Рюриковичей, царь Федор Иванович, скончался в 1598 г. Неудивительно, что в начале XVII в. интерес к Степенной книге заметно угас. События разворачивались явно вопреки намеченной в Степенной книге схеме, которая главным гарантом процветания Русской земли представляет царствующий род Рюриковичей.

Замечательно, что в XVII в. предпринимались неоднократные попытки модернизировать концепцию Степенной книги, согласовать еe c 
современными реалиями, что в данном случае означает включение в «золотую лестницу» русской истории династии Романовых. Через некоторое время после написания Степенной книги ее текст, который изначально был доведен до 1560 г. и оканчивался XVII посвященной Ивану Грозному степенью, стали продолжать, присоединяя к нему тексты различных документов, выписки из летописей, хронографов, публицистических произведений и пр. Эта традиция дожила до начала XVIII в. Первым проявлением этой традиции можно считать рукопись 90-х гг. XVI в. РНБ, Эрм. 385, в которой после текста Степенной книги помещено Соборное определение на четверный брак Ивана Грозного (самый ранний из известных списков), а одним из последних так называемый Летописец славянороссийский (самый ранний список РНБ, F.IV.226) - объемную компиляцию 1698 г., в основу которой положена Степенная книга, продолженная на основании различных источников до 90-х гг XVII в. 30-ми гг. XVII в. датируется первая попытка оформить повествование о Федоре Ивановиче в XVIII степень. В рукописи 30-х гг. XVII в. БАН, 32.8.1, содержащей текст Краткой редакции Степенной книги, повествование о царствовании царя Федора Ивановича следует тексту Хронографа 1617 г. и имеет заимствованный оттуда же заголовок «Царство государя царя и великаго князя Феодора Ивановича всеа Русии», который продолжен словами «Степень осмыйнадесят, грань 18» (л. 1130 об.). По-видимому, прибавленные слова - это творчество переписчика рукописи, поскольку другие списки, восходящие к общему с ней протографу (РГАДА, ф. 357 (собр. Саровской пуст.) 59, РГАДА, ф. 181 (собр. МГАМИД) 366, РНБ, F.IV.596, РНБ, Эрм. 393, РНБ, Погод. 1430), их не содержат. Не ранее середины XVII в. появился список Степенной книги, в котором выписки из различных источников, посвященные царствованию Федора Ивановича, были также оформлены в виде XVIII степени. Этот список, по всей видимости, не сохранился. Во всяком случае, нам известны только списки, восходящие к нему. Все они содержат текст Степенной книги младшего извода Пространной редакции, который появился в 40-е гг. XVII в. В списке 50-х гг. XVII в. БАН, Арханг. С. 131 повествование о царствовании Федора Ивановича, заимствованное из Хронографа редакции 1617 г., оформлено в виде XVIII степени следующим образом: к заголовку «Царство государя царя и великаго князя Феодора Ивановича всея Росии самодержца» прибавлено «степень и грань 18-я» (л. 663). В списке того же времени РНБ, Соф. 1378 под заголовком XVIII степени помещен текст Нового летописца, причем заголовок составлен в том же стиле, что и заголовки всех 17-ти степеней Степенной книги: «Степень осмыйнадесять и грань осмая надесять, в ей же митрополит Дионисий и первый патриарх Иов, глав же имать» (л. 757). Восходящий к этой рукописи список Нового летописца ф. 256 (собр. Н.П. Румянцева) 259, который также содержит заголовок XVIII степени, дал 
повод П.Г. Васенко предположить, что Новый летописец изначально был задуман как продолжение Степенной книги ${ }^{3}$. Это неаргументированное предположение отвел Л.В. Черепнин, и как очевидно теперь, он был совершенно прав ${ }^{4}$. Список Соф. 1378 скорее похож на рукопись, созданную в монастырском скриптории. К протографу, общему с Арханг. С. 131 и Соф. 1378, восходит и список 3-й четверти XVII в. НБУВ, ф. 302 (собр. митр. Макария) П.49, в котором к тексту XVII грани присоединены первое послание Курбского Грозному, первое послание Грозного Курбскому, выписки из Жития митрополита Филиппа и Хронографа редакции 1617 г. После известия о кончине Ивана Грозного помещена следующая концовка: «Дозде седмыйнадесят степень и конец грани седмыя же надесять, и царствия Феодора Ивановича достигше, глаголем елико разума подаст Бог» (л. 167 об.-168), которая воспроизводит концовки степеней Степенной книги. Далее продолжаются выписки из Хронографа редакции 1617 г., и против первого заголовка «Царство государя и великаго князя Феодора Ивановича всеа Русии самодержца» на поле в картуше написано «18 степень» (л. 168). Можно назвать еще несколько списков Степенной книги, восходящие к этой традиции, и все они содержат так или иначе оформленный заголовок XVIII степени ${ }^{5}$. Важно отметить, что их протограф никак не связан со списком БАН 32.8.1, поскольку они содержат разные редакции Степенной книги. Пожалуй, их объединяет только время создания - 30-50-е гг. XVII в. Видимо, именно тогда назрела необходимость продолжить текст Степенной книги. Характерно, что решить эту задачу удалось только относительно царствования последнего представителя династии Федора Ивановича. Дальнейшее повествование организовать в степени не удалось.

Итак, активное обращение к Степенной книге началось примерно в 40-е гг. XVII в. В Троице-Сергииевом монастыре священник Иоанн Милютин привлек Степенную книгу к составлению Четьих Миней. Из Степенной книги им были выписаны княжеские биографии, и сделанные выписки вплетены в рукописные тома Миней. Каждая выписка составила, таким образом, отдельное княжеское житие. При этом некоторые из попавших таким образом в Четьи Минеи князей не были канонизированы ни тогда, ни в последующее время. На основе Степенной книги составлялись агиографические произведения и в окружении патриарха Иосифа (1642-

3. П.Г. Васенко, Заметки к Латухинской Степенной книге, СПб., 1902, с. 60-61.

4. Л.В. Черепнин, “"Смута” и историография XVII в. », ИЗ, 14, М., 1945, с. 108-109 ; В.Г. Вовина-Лебедева, Новый летописещ: история текста, СПб., 2004, с. 163. Вызывает сомнение, однако, оправданность высказанного Л.В. Черепниным предположения, что соединение Степенной книги и Нового летописца произошло в Записном приказе. В списке Соф. 1378 никаких подтверждений этому не находим.

5. Например, списки, восходящие к Соф. 1378 : ГИМ, собр. Е.В. Барсова 1852 ; БАН, 16.12.1 ; РГАДА, ф. 187 (собр. ЦГАЛИ), оп. 2, № 96а ; ГИМ, собр. Покровского собора 103799/301. Списки, восходящие к Макарий 49 : списки упомянутого выше Летописца славянороссийского и РГАДА, ф. 181 (собр. МГАМИД) 352. 
1652 гг.). В 1645 г. Иосиф принял активное участие в канонизации владимирского князя Георгия Всеволодовича. Книжниками его круга был составлен цикл житийных произведений, посвященных владимирским князьям. Одним из главных источников этих произведений стала Степенная книга ${ }^{6}$. Пожалуй, наиболее выдающимся книжником из окружения патриарха Иосифа был соловецкий монах Сергий Шелонин. Среди его литературного наследия к рассматриваемой теме имеет отношение так называемый Хронограф, помещенный в конвое к составленному Сергием Азбуковнику РНБ, собр. Соловецкого монастыря, 18/18 на л. 566-6237. Введенный в научный оборот О.В. Панченко, Хронограф Сергия Шелонина в сущности представляет собой выписки из Степенной книги с добавлением уникальных известий по истории Смутного времени ${ }^{8}$. Текст здесь так же разделен на степени, как и в оригинальном тексте Степенной книги. Новшество Сергия заключается в том, что он попытался продолжить текст Степенной до середины XVII в. После XVII степени в Хронографе помещена посвященная царю Федору Ивановичу XVIII степень. В состав этой степени включено и повествование о Борисе Годунове и Лжедмитрии I. Не считать Лжедмитрия законным царем было обычной практикой историографии XVII в., а в отношении Бориса Годунова Сергию пришлось идти вразрез с общепринятой точкой зрения, согласно которой Бориса считали законным царем, которого избрал на царство Земский собор. Но иначе никак не объяснить, почему Борису Годунову не посвящено самостоятельного раздела. Поэтому Сергий заявил, что Борис стал царем обманным путем: «хитростройными пронырствы престол царства великия державы руския восхити и самодержец наречеся» (л. 624). Далее следует посвященная Василию Шуйскому XIX степень. Василий Шуйский объявляется продолжателем династии: «иже бысть от сродства великого князя Ярослава Всеволодича, внука великого князя Георгия Долгоруково, правнука Владимира Манамаха» (л. 626 об.). Следующая XX степень посвящена Михаилу Федоровичу Романову. Удивительно, что и он, согласно конструкции Сергия Шелонина, относится к династии Рюриковичей, а это уже явная натяжка. Михаил Федорович был всего лишь двоюродным

6. См. об этом: А.В. Сиренов, сост., Путь к граду Китежу. Князь Георгий Владимирский в истории, житиях, легендах, СПб., 2003, с. 24-87.

7. Азбуковник Сергия Шелонина представляет собой ценный источник, разностороннее исследование которого только начинается: А.Н. Левичкин, 1) « Азбуковник - вклад Сергия Шелонина в Соловецкую библиотеку », Духовная культура: История $u$ тенденция развития. 1-5 июня 1992 г. Тезисы докладов, Сыктывкар, 1992, т. 2, р. 111112 ; 2) « Лексикографические труды Сергия Шелонина », Русский язык, Сб. ст., СПб., 1999, с. 52-53; О.С. Сапожникова, « Азбуковник Сергия Шелонина и идеология Соловецкого восстания », Международная научная конференция «Книжное наследие Соловецкого монастыря XV-XVII вв.» 5-10 сентября 2005 года: Тезисы, Соловки, 2005 , с. $38-42$.

8. О.В. Панченко, « Сергий Шелонин как историограф », там же, с. 42-48. 
племянником по женской линии царя Федова Ивановича. По мнению автора Хронографа, этого достаточно для преемственности династии. Михаил Федорович, по его словам, «седе на престоле Российского государства прародителей своих и дяди своего царя и великого князя Феодора Ивановича всеа Руси» (л. 634 об.). Насчет наследования дяде с рассуждениями Сергия согласиться можно, так как Федор Иванович приходился Михаилу Федоровичу хотя и двоюродным, но дядей. Зато совершенно очевидно, что «прародители» Михаила Романова на царском престоле никогда не сидели. XXI степень определена для Алексея Михайловича, который «седее на престоле Российского государства прародителей своих и деда своего царя и великого князя Феодора Ивановича всеа Руси и отца своего царя и великого князя Михаила Феодоровича всеа Русии» (л. 635). Таким образом, Сергий Шелонин попытался преодолеть кризис идеи Степенной книги, связав всех правителей России конца XVI-середины XVII в. в одну династию. Неубедительность такого построения очевидна. Возможно, поэтому произведение Сергия Шелонина не получило популярности и известно ныне в одном списке, принадлежавшем некогда самому автору.

В 1657 г. по указу Алексея Михайловича был учрежден специальный Записной приказ, задачей которого стало продолжение Степенной книги до современности, т.е. до середины XVII в. Дошедшие до нас документы Записного приказа свидетельствуют о том, что за два года его существования были предприняты лишь малоэффективные попытки собрать материал для историографической работы. Чем закончилось это мероприятие, и была ли в результате создана новая редакция Степенной книги, неизвестно 9 Показательно, во-первых, осознание властью необходимости создать концептуальное изложение отечественной истории от древности до современности, и во-вторых, неспособность решить эту задачу на основе Степенной книги. Следовало вписать в исторический процесс династию Романовых как легитимную наследницу Рюриковичей на русском престоле. Степенная книга напрямую связывала историческое развитие страны с чередованием поколений династии Рюриковичей. Чиновники Записного приказа должны быти обратиться к концепции Степенной книги, в которой Романовым, в сущности, места не было. Повидимому, решение, подобное тому, какое предложил Сергий Шелонин объявить Романовых потомками Рюриковичей на основании родства по женской линии, не представлялось удачным. Действительно, в стране, где жили многочисленные представители разных ветвей рода Рюриковичей, едва ли могла получить популярность идея о легитимности продолжения этой династии по женской линии.

9. С.А. Белокуров, « О Записном приказе », Из духовной жизни московского общества XVII в., М., 1903, с. 53-84 ; М.П. Лукичев, Б.Н. Морозов, « К истории организации официального летописания XVII в. », AE 1992, М., 1994. с. 134-144. 
Видимо, неспособностью согласовать концепцию Степенной книги с политической конъюнтктурой и следует объяснять отсутствие новых редакций Степенной книги в середине - третьей четверти XVII в. В 1667 г. дьяк Федор Акимович Грибоедов по царскому приказу написал «Историю о царях и великих князьях русских», которая в приказной документации называлась Степенной книгой ${ }^{10}$. Действительно, основным источником этого труда стала Степенная книга. Повествование Ф.А. Грибоедовым доведено до середины XVII в., однако в нем отсутствует разделение на степени, что является жанрообразующим признаком Степенной книги ${ }^{11}$. Ф.А. Грибоедов написал, таким образом, исторический трактат, использовав Степенную книгу в качестве основного источника. K произведениям подобного типа следует отнести и составленный в 1674 г. Титулярник. Эти произведения никак не развивают концепцию Степенной книги и даже не обращаются к ней.

Новая редакция собственно Степенной книги появилась только в 1679 г. - так называемая Латухинская Степенная (так назвал ее М.Н. Карамзин по имени владельца одного из списков). Она была написана монахом Макарьева-Желтоводского монастыря Тихоном. Этот монастырь был основан в нижегородских краях на урочище «Желтые воды» еще в первой половине XV в. преподобным Макарием, но в 1439 г. разорен татарами. В Смутное время почитание преп. Макария стало особенно активным в нижегородском ополчении ${ }^{12}$. В 1629 г. монастырь был воссоздан, пользовался покровительством цари и патриарха и стал одним из интеллектуальных церковных центров страны ${ }^{13}$. С ним связано начало деятельности выдающихся церковных деятелей середины - второй половины XVII в.. В свете изложенного не должно показаться странным, что новая редакция Степенной книги возникла в стенах Макарьева-Желтоводского монастыря. Тихон (впоследствии он получил прозвище Макарьевский) привлек к составлению новой редакции Степенной книги множество источников. Кроме канонического текста Степенной книги можно назвать Синопсис Иннокнтия Гизеля издания 1678 г., Патриарший летописный свод 1652 г., Казанскую историю, Киево-Печерский патерик, памятники сибирского летописания XVII в., Воскресенскую летопись, Повесть о начале

10. РГАДА, ф. 396 (Оружейная палата), оп. 1, ч. 9, № 12121 : Указ о пожаловании разрядного дьяка Федора Грибоедова за Степенную книгу благоверного и благочестивого рода Романовых, 1668 г.

11. С.Ф. Платонова, В.В. Майкова, отв. ред, « История о царях и великих князьях земли Русской (По списку СПбДА № 306) », ПДП, т. 121, СПб., 1896 ; Е.К. Ромодановская, « Грибоедов Федор Акимович », СККДР, III/1, с. 230-233.

12. Н.В. Понырко, « Обновление Макариева Желтоводского монастыря и новые люди XVII в. - ревнители благочестия », ТОДРЛ, т. 43, Л., 1990, с. 58-69.

13. В.В. Зверинский, Материал для историко-топографического исследования о православных монастырях в Российской империи, кн. 1, СПб., 1890, с. 175-176. 
Москвы и многие другие. Но самое главное, что Тихон изменил композицию Степенной книги. Традиционное деление текста на степени (поколения Рюриковией) он применил не для всего текста, а для периода с крещения Руси, т.е. с княжения Владимира Святого, до княжения Василия III. Сын последнего Иван Грозный стал первым русским царем. Начиная с него Тихон ввел иное членение текста - на царства, принятое в хронографической традиции (например, в редакциях русского Хронографа 1617 г. и 1620 г.). Здесь уже не столь важны были родственные связи предшественника и преемника. Согласно концепции Тихона получалось, что святой род Рюриковичей учредил в России царство, во главе которого впоследствии оказывались наиболее способные правители. Так, правление Ивана Грозного названо 1-м царством, его сына Федора - 2-м царством, Бориса Годунова 3-м царством, Лжедмитрия I - 4-м царством, Василия Шуйского - 5-м царством, Михаила Романова - 6-м царством, Алексея Михайловича - 7-м царством, а Федора Алексеевича - 8-м царством.

Рукопись созданной им Пространной редакции Латухинской Степенной (ныне Нижегородская областная библиотека, Ц-2658/2) Тихон вложил в 1679 г. в Макарьев-Желтоводский монастырь ${ }^{14}$, но сам в монастыре не остался. С этого времени началась его блестящая церковная карьера, которую он закончил казначеем последнего русского патриарха Адриана (а следовательно, и главой Патриаршего казенного приказа), а после его смерти - душеприказчиком ${ }^{15}$. Последние распряжения Тихона Макарьевского на этом посту датируются 1707 г. ${ }^{16}$ В 1703 г. по инициативе и, можно думать, с личным участием Тихона была создана еще одна редакция Степенной книги. Она дошла в четырех списках БАН, Арханг. К. 52, БАН, 34.4.15, Государственный архив Ярославской области, колл. рукописей, 53, ГИМ, Синод. собр. 151. В ее основе - составленная Тихоном Латухинская Степенная. Однако на этот раз русскую историю соединили с библейской, античной и византийской, для чего привлекли одну из редакций Хронографа. По этой причине новую редакцию можно назвать Хронографической редакцией Латухинской Степенной. Русская часть ее повествования оказалась продолжена до 1703 г. - так появилось посвященное Ивану и Петру Алексеевичам 9-е царство. Один из списков Хронографической редакции, Ярославский, Тихон по завещанию передал в родной Макарьев монастырь.

14. Л.Л. Муравьева, «О списках Латухинской степенной книги, $A E$ 1964, М., 1965, c. $89-90$.

15. К этому следует прибавить, что Тихон составил музыкально-теоретический трактат «Ключ разумения», а также является автором нескольких вирш (Д.М. Буланин, Е.К. Ромодановская, « Тихон Макарьевский », СККДР, 3/4, СПб., 2004, с. 31-42.

16. «Грамота Петра I на построение Никольской церкви в городе Черкасске », Донская церковная старина, т. 1, 1906, с. 153-154. 
В 20-е гг. XVIII в. в Макарьеве-Желтоводском монастыре появилась Краткая редакция Латухинской Степенной, составленная с привлечением Пространной и хронографической редакций (архетипный список этой редакции - РГБ, ф. 228 (собр. Д.В. Пискарева) 179). Основой стала Пространная редакция, в которой было произведено последовательное сокращение агиографических текстов, из Хронографической редакции заимствовано лишь повествование с 1779 до 1703 гг. Далее текст был продолжен до 1727 г., появились царства 10-е - Екатерины I и 11-е Петра II.

Так историографическая мысль XVII в. преодолела противоречие концепции Степенной книги и последствий династического кризиса конца XVI - начала XVII в. Латухинская Степенная была весьма популярна в русской исторической литературе XVIII в., но духу эпохи Просвещения она не соответствовала, поэтому использовалась историками лишь как источник фактического материала.

Université d'État de Saint-Pétersbourg

Faculté d'histoire

sirenov@rambler.ru 